\title{
Optimization of textile azo dye degradation by electrochemical oxidation using Box-Behnken Design
}

\author{
Kaouthar Oukili * and Mohammed Loukili \\ Department of Process, Environment and Renewable Energy, University Sidi Mohamed Ben Abdellah, High \\ School of Technology, 2427 Route Imouzzer, Fez, Morocco
}

\begin{abstract}
Degradation of textile azo dye solutions containing Methyl Orange by anodic oxidation using an electrochemical reactor was studied. The combined effect of independent parameters (current intensity, initial $\mathrm{pH}$ and electrolysis time) on color removal efficiency was investigated and optimized using response surface methodology. A Box-Behnken design was successfully employed for experimental design. The obtained quadratic model was statistically tested using analysis of variance (ANOVA). Results showed that the optimal operating conditions to achieve $98.51 \%$ efficiency for color removal were current intensity $=4.6 \mathrm{~A}$, initial $\mathrm{pH}=4$ and electrolysis time $=65 \mathrm{~min}$, at a dye concentration and temperature of $50 \mathrm{mg} / \mathrm{L}$ and $25^{\circ} \mathrm{C}$, respectively.
\end{abstract}

Keywords: Anodic oxidation; Box-Behnken design; response surface methodology; wastewater treatment; anodic oxidation; azo dye.

\section{Introduction}

The textile industry is regarded as one of the most polluting sector ${ }^{1}$ since it consumes large quantities of wastewaters with high azo dye contents, which are discharged into water bodies. Among these dyes, azo dyes are extensively used in textile industries ${ }^{2,3}$. These colored effluents are characterized by intense color, high chemical oxygen demand (COD) and stable chemical structure due to the existence of azo groups $(-\mathrm{N}=\mathrm{N}-)$, which are responsible for dye color ${ }^{4}$. The presence of such kinds of dye effluents in the aquatic environment can cause many environmental problems because they are toxic and interfere in photosynthetic processes by consuming the oxygen needed for living species ${ }^{5}$.

Decontamination of dyes wastewater can be achieved through a considerable number of processes, such as adsorption ${ }^{6,7}$, coagulation ${ }^{8}$, ozonation ${ }^{9}$, photocatalytic ${ }^{10}$ and electrochemical oxidation methods. Amongst these processes, electrochemical treatments have received great attention for the removal of recalcitrant organic compounds from waters. Electrooxidation (EO) is one of the most promising electrochemical technologies for the removal of toxic and persistent organic pollutants from waters ${ }^{11}$. The contaminants are destroyed by either the direct or indirect oxidation. Direct oxidation takes place directly at the anode, where the pollutants are destroyed by electron transfer reaction. In indirect oxidation, strong oxidants, such as hydroxyl radicals $\left({ }^{\circ} \mathrm{OH}\right)$, hypochlorite/chlorine, ozone, and hydrogen peroxide are generated on the anode surface and then chemical oxidation takes place ${ }^{12}$. The effectiveness of this process strongly depends on the electrode material and operational conditions.

Several research groups have reported the electrochemical oxidation of dyes in water using various electrodes materials. Rajkumar et al. ${ }^{13}$ studied the treatment of C.I. Re-active Yellow 186 by EO using graphite electrodes. A maximum decolorization efficiency of $99 \%$ and COD removal $73 \%$ was achieved under the optimized condition ( $\mathrm{pH} 3.9 ; \mathrm{NaCl}$ concentration $0.11 \mathrm{M}$; and electrolysis time $18 \mathrm{~min}$ ). Cotillas and coworkers ${ }^{14}$ used boron-doped diamond (BDD) electrodes to oxidize Red MX-5B dye in aqueous solutions. The results showed a full dye and COD removal after 240 min of electrolysis. Elaissaoui et al. ${ }^{15}$ studied the degradation of Amaranth in aqueous solution using $\mathrm{PbO}_{2}$ anode and they reported COD and color removals of 84 and $100 \%$, respectively. Isarain-Chávez et al. ${ }^{16}$ compared the oxidation behavior of five different DSA anodes (Ti/Ir-Pb, Ti/Ir-Sn, Ti/Ru-Pb, Ti/Pt-Pd, and Ti/RuO ${ }_{2}$ ) for $\mathrm{EO}$ of methyl orange azo dye solutions. The results showed that the best performance (74\% of COD removal) was achieved using $\mathrm{Ti} / \mathrm{Ir}-\mathrm{Pb}$ anode. DSA electrodes $(\mathrm{Ti} / \mathrm{Pt})$ present high catalytic activity, especially for chlorine generation, as well as high mechanical stability. However, these anodes have a major drawback of toxic by-products formation ${ }^{17,18}$, consequently, more studies must be performed. In this context, the present study aims to evaluate the performance of the EO process with $\mathrm{Ti} / \mathrm{Pt}$ electrodes.

An experimental design based on Response Surface Methodology (RSM) was used to optimize 
the effects of various experimental parameters to reach the best system performance. In fact, the experimental design is a helpful tool to study a large number of factors with the minimum experimental runs ${ }^{19}$. Additionally, the possible interactions between factors can be evaluated ${ }^{20}$. RSM is a mathematical and statistical method for designing experiments, building models and can be used to evaluate the relative significance of variables. The main objective of RSM is to determine optimum values of operating conditions to predict target response ${ }^{21}$. Box-Behnken design (BBD) is among the principal response surface methodologies used in experimental design ${ }^{22}$. It's an independent, rotatable second-order design and requires fewer runs than the other design methods. It has been applied for optimization of several processes ${ }^{23,24}$. In the present work, a Box-Behnken experimental design has been chosen to optimize several experimental parameters (current intensity, initial $\mathrm{pH}$ and electrolysis time) that have significant effects on color removal efficiency of azo dye Methyl Orange (MO) by EO.

\section{Experimental}

\section{Anodic oxidation experiments}

The degradation of MO dye was carried out using a cylindrical tank reactor of $6 \mathrm{~L}$ capacity, equipped with an external water-jacket to maintain the solution temperature at $25^{\circ} \mathrm{C}$ using a ULTRATEMPS 2000 julabo F30 thermostat. The anode was a cylindrical platinized titanium $(\mathrm{Ti} / \mathrm{Pt})$ grid and the cathode was a rod of the same metal. These electrodes were connected to the DC power supply (EA-7015-050). The solution was constantly stirred at $300 \mathrm{rpm}$ to ensure homogeneity using a BIOBLOCK SCIENTIFIC stirrer. Each assay was performed using a solution containing $50 \mathrm{mg} / \mathrm{L}$ concentration of $\mathrm{MO}$. $\mathrm{NaCl}, \mathrm{KCl}$ and $\mathrm{Na}_{2} \mathrm{SO}_{4}$, at concentration $2.5 \mathrm{~g} / \mathrm{L}$, were evaluated as an electrolyte in order to know their effect on the degradation of MO. During the experiment, samples were withdrawn at different time intervals and analyzed. The solution $\mathrm{pH}$ was determined using a $\mathrm{pH}$ meter (Hach) and adjusted with sulfuric acid or sodium hydroxide. The color removal efficiency of dye solutions was monitored using a UV-Vis 1201 Shimadzu spectrophotometer at $460 \mathrm{~nm}$, the maximum wavelength of MO (Figure 1), at different time intervals. The percentage of color removal efficiency $(\% \eta)$ was calculated as follows:

$\% \eta=\frac{A_{0}-A_{t}}{A_{0}} * \mathbf{1 0 0}$

Where $\mathrm{A}_{0}$ and $\mathrm{A}_{t}$ are the absorbance at the initial time and time $t$ at the characteristic $\lambda \max =460$.

(a)

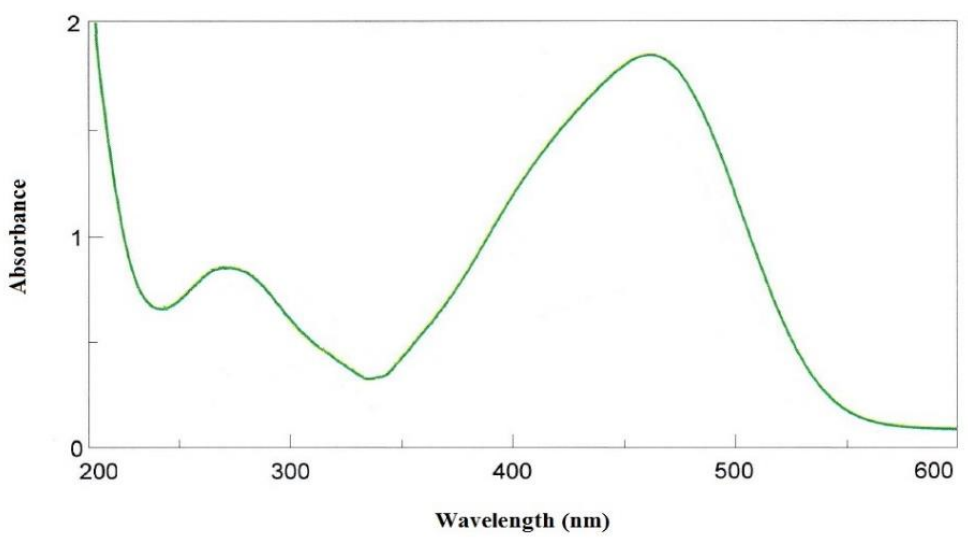

(b)

(c)<smiles>CN(C)c1ccc(/N=N/c2ccc(S(=O)(=O)O)cc2)cc1</smiles>

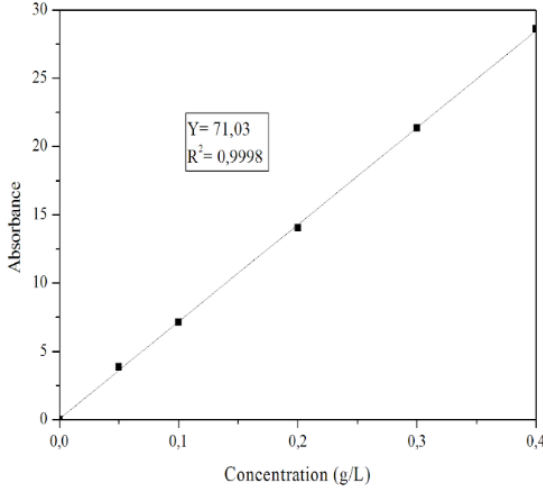

Figure 1. (a) Absorption spectra of $\mathrm{MO}(50 \mathrm{mg} / \mathrm{L})$ before treatment, (b) azo dye structure and (c) calibration plot of solution at $460 \mathrm{~nm}$. 


\section{Experimental design}

Box-Behnken design and the response surface methodology were carried out in order to visualize the effects of operating parameters on the degradation of MO dye. The main selected factors were current density $\left(\mathrm{X}_{1}\right)$, initial $\mathrm{pH}\left(\mathrm{X}_{2}\right)$ and electrolysis time $\left(\mathrm{X}_{3}\right)$. Box-Behnken design requires an experiment number according to $\mathrm{N}=\mathrm{k}^{2}+\mathrm{k}+\mathrm{cp}$, where $(\mathrm{k})$ is the factor number and (cp) is the replicate number of the central point ${ }^{25}$.
In this study, a design of 15 experiments was formulated based on 3 levels and a 3 factors experimental design, with 3 replicates at the center of the design for estimation of a pure error sum of squares ${ }^{26}$. The independent variables were coded with low level $(-1)$, center $(0)$ and high level $(+1)$ as illustrated in Table 1, while color removal was the response (dependent variable). The experimental levels for each factor were selected on the basis of the preliminary results of the study.

Table 1. Experimental ranges and levels of the independent variables.

\begin{tabular}{|c|c|c|c|c|}
\hline Independent variable & Factor & \multicolumn{3}{|c|}{ Coded levels } \\
\cline { 3 - 4 } & & -1 & 0 & +1 \\
\hline Current intensity (A) & $\mathrm{X}_{1}$ & 3 & 4 & 5 \\
\hline $\mathrm{pH}$ & $\mathrm{X}_{2}$ & 4 & 7 & 10 \\
\hline Electrolysis time (min) & $\mathrm{X}_{3}$ & 30 & 60 & 90 \\
\hline
\end{tabular}

Data from the Box-Behnken design was analyzed and

fitted to a second-order polynomial model,

$\mathrm{Y}=\beta_{0}+\beta_{1} \mathrm{X}_{1}+\beta_{2} \mathrm{X}_{2}+\beta_{3} \mathrm{X}_{3}+\beta_{12} \mathrm{X}_{1} \mathrm{X}_{2}+\beta_{13} \mathrm{X}_{1} \mathrm{X}_{3}+\beta_{23} \mathrm{X}_{2} \mathrm{X}_{3}+\beta_{11} \mathrm{X}_{21}+\beta_{22} \mathrm{X}_{22}+\beta_{33} \mathrm{X}_{23}$

Where $\mathrm{Y}$ is the response, i.e. the color removal; $\mathrm{x}_{\mathrm{i}}$ and $\mathrm{x}_{\mathrm{j}}$ are the independent factors, $\beta_{0}$ is the constant coefficient, $\beta_{\mathrm{i}}$ represents the coefficient that determines the influence of factor $\mathrm{i}$ in the response (linear term), $\beta_{\mathrm{ij}}$ refers to the effect of the interaction among variables $\mathrm{i}$ and $\mathrm{j}$, $\beta \mathrm{ii}$ is the parameter that determines the shape of the curve (quadratic effect) 27,28 . The experimental design, analysis of variance (ANOVA) and 3D response surface were performed using the software Minitab (version 16).

\section{Results and Discussion}

\section{Effect of electrolyte}

The effect of nature of supporting electrolyte on the dye removal efficiency was investigated. Figure 2 shows the decay of MO with electrolysis time using different supporting electrolytes $(\mathrm{NaCl}, \mathrm{KCl}$, and $\mathrm{Na}_{2} \mathrm{SO}_{4}$ ). It can be seen that the complete removal of dye is achieved in the presence of the $\mathrm{KCl}$ and $\mathrm{NaCl}$. The graph shows that the decrease of $\mathrm{MO}$ concentration in the presence of $\mathrm{KCl}$ or $\mathrm{NaCl}$ is more rapid than that in the presence of $\mathrm{Na}_{2} \mathrm{SO}_{4}$. It is well known that organic pollutants present in wastewater are primarily destroyed via indirect oxidation by strong oxidants such as hypochlorite/chlorine, generated from the anodic oxidation of chloride.

$$
\begin{aligned}
& 2 \mathrm{Cl}^{-} \rightarrow \mathrm{Cl}_{2}+2 \mathrm{e}^{-} \\
& \mathrm{Cl}_{2}+\mathrm{H}_{2} \mathrm{O} \rightarrow \mathrm{HOCl}+\mathrm{H}^{+}+\mathrm{Cl}^{-} \\
& \mathrm{HOCl} \rightarrow \mathrm{H}^{+}+\mathrm{OCl}^{-}
\end{aligned}
$$

It seems that the presence of chloride plays an important role in the degradation efficiency of the EO process via the quite effective action of chlorine/hypochlorite produced during electrolysis. Therefore, the rest of experiments were performed using $\mathrm{NaCl}$ as supporting electrolyte.

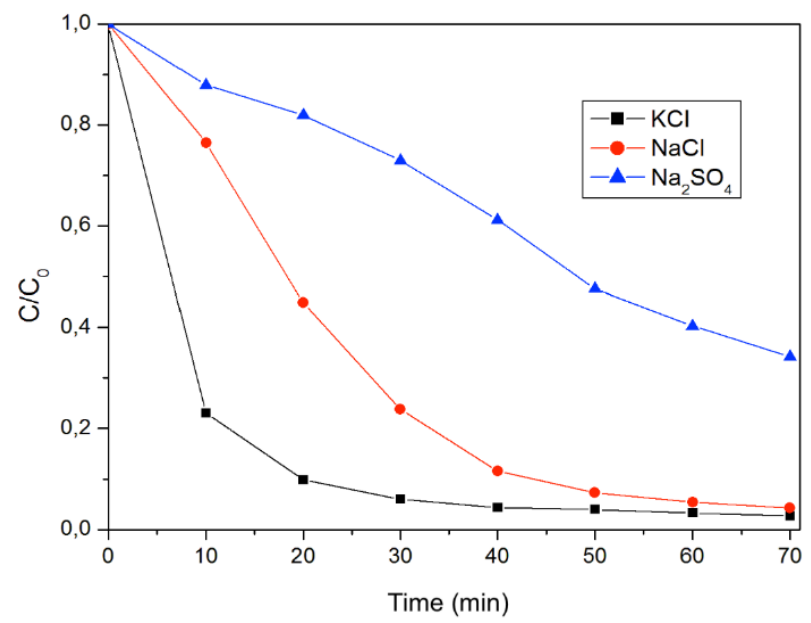

Figure 2. Influence of supporting electrolyte on $\mathrm{MO}$ removal $\left(\mathrm{C}_{0}=50 \mathrm{mg} / \mathrm{L}\right)$ at $\mathrm{pH} 7.3$ using an undivided cell at $5 \mathrm{~A}$ and different electrolytes $\left(\mathrm{Na}_{2} \mathrm{SO}_{4} ; \mathrm{NaCl} ; \mathrm{KCl}\right)$ 


\section{Optimization of the anodic oxidation of MO}

The experimental results obtained in the trials performed with the Box-Behnken design are presented in Table 2.

Table 2. Experimental design results.

\begin{tabular}{|c|c|c|c|c|c|c|c|}
\hline \multirow[t]{2}{*}{ Run } & \multirow{2}{*}{$\begin{array}{l}\text { Current } \\
\text { intensity } \\
\text { (A) }\end{array}$} & \multirow{2}{*}{$\begin{array}{c}\text { Initial } \\
\mathrm{pH}\end{array}$} & \multirow{2}{*}{$\begin{array}{l}\text { Electrolysis } \\
\text { Time (min) }\end{array}$} & \multicolumn{3}{|c|}{ Coded level of variable } & \multirow{2}{*}{$\begin{array}{c}\% \text { MO color } \\
\text { removal }\end{array}$} \\
\hline & & & & $\mathrm{X}_{1}$ & $\mathrm{X}_{2}$ & $\mathrm{X}_{3}$ & \\
\hline 1 & 3 & 4 & 60 & -1 & -1 & 0 & 91.54 \\
\hline 2 & 5 & 4 & 60 & 1 & -1 & 0 & 97.97 \\
\hline 3 & 3 & 10 & 60 & -1 & 1 & 0 & 45.02 \\
\hline 4 & 5 & 10 & 60 & 1 & 1 & 0 & 68.21 \\
\hline 5 & 3 & 7 & 30 & -1 & 0 & -1 & 51.60 \\
\hline 6 & 5 & 7 & 30 & 1 & 0 & -1 & 71.78 \\
\hline 7 & 3 & 7 & 90 & -1 & 0 & 1 & 89.51 \\
\hline 8 & 5 & 7 & 90 & 1 & 0 & 1 & 95.75 \\
\hline 9 & 4 & 4 & 30 & 0 & -1 & -1 & 90.12 \\
\hline 10 & 4 & 10 & 30 & 0 & 1 & -1 & 43.03 \\
\hline 11 & 4 & 4 & 90 & 0 & -1 & 1 & 96.55 \\
\hline 12 & 4 & 10 & 90 & 0 & 1 & 1 & 78.06 \\
\hline 13 & 4 & 7 & 60 & 0 & 0 & 0 & 86.16 \\
\hline 14 & 4 & 7 & 60 & 0 & 0 & 0 & 85.71 \\
\hline 15 & 4 & 7 & 60 & 0 & 0 & 0 & 86.42 \\
\hline
\end{tabular}

The rate of color removal varied between $43 \%$ and $97 \%$. The second-order polynomial model (Eq. (6)) that established the correlation between the dye removal and the independent factors (in terms of coded values) can be predicted using the coefficients given in Table 3.

$\eta(\%)=86.10+7.01 X_{1}-17.73 X_{2}+12.91 X_{3}-5.09 X_{1}^{2}+5.32 X_{2}^{2}-3.84 X_{3}^{2}+4.19 X_{1} X_{2}-3.48 X_{1} X_{3}+7.15$ $\mathrm{X}_{2} \mathrm{X}_{3}$

The effect of initial $\mathrm{pH}$ on response is negative, while the effects of current intensity and electrolysis time are positive. Probability $(\mathrm{P})$ values were used as a tool to evaluate the significance of each coefficient ${ }^{29}$. The values of $P$ less than 0.050 indicate that model terms have a significant influence on the dye removal efficiency (for a confidence level of $95 \%$ or more), whereas values greater than 0.100 are not significant.

Table 3 shows that the effects of initial $\mathrm{pH}$ and electrolysis time on color removal were highly significant with $\mathrm{P}$ values close to zero, followed by the effect of current intensity $(\mathrm{P}=0.003)$. The factors that had relatively less effect on color removal efficiency were the interactions between electrolysis time and initial $\mathrm{pH}(\mathrm{P}=0.012)$ and the quadratic terms of initial $\mathrm{pH}(\mathrm{P}=0.039)$ and current intensity $(\mathrm{P}=0.045)$. The interaction between current intensity and electrolysis time $(\mathrm{P}=0.117)$ and the quadratic terms of electrolysis time $(\mathrm{P}=0.102)$ were insignificant (P-value more than 0.1 ) and hence removed to obtain statistically significant regression model.

$\eta(\%)=86.10+7.01 X_{1}-17.73 X_{2}+12.91 X_{3}-5.09 X_{1}^{2}+5.322 X_{2}^{2}+4.19 X_{1} X_{2}+7.15 B X_{2} X_{3}$

Table 3. Estimated regression coefficients and corresponding t and $\mathrm{P}$ values from the data of Box-Behnken design experiment.

\begin{tabular}{|c|c|c|c|c|}
\hline Term & Coefficient & Standard error & t-Value & P-Value \\
\hline Constant & 86.10 & 2.128 & 40.461 & 0.000 \\
\hline $\mathrm{X}_{1}$ & 7.01 & 1.303 & 5.375 & 0.003 \\
\hline $\mathrm{X}_{2}$ & -17.73 & 1.303 & -13.607 & 0.000 \\
\hline $\mathrm{X}_{3}$ & 12.91 & 1.303 & 9.912 & 0.000 \\
\hline $\mathrm{X}_{1} * \mathrm{X}_{1}$ & -5.09 & 1.918 & -2.656 & 0.045 \\
\hline $\mathrm{X}_{2} * \mathrm{X}_{2}$ & -5.32 & 1.918 & -2.772 & 0.039 \\
\hline $\mathrm{X}_{3} * \mathrm{X}_{3}$ & -3.84 & 1.918 & -2.003 & 0.102 \\
\hline $\mathrm{X}_{1} * \mathrm{X}_{2}$ & 4.19 & 1.843 & 2.276 & 0.072 \\
\hline $\mathrm{X}_{1} * \mathrm{X}_{3}$ & -3.48 & 1.843 & -1.890 & 0.117 \\
\hline $\mathrm{X}_{2} * \mathrm{X}_{3}$ & 7.15 & 1.843 & 3.880 & 0.012 \\
\hline
\end{tabular}


Table 4 shows the analysis of variance (ANOVA) results from this model, where the regression model for color removal was significant with $\mathrm{P}$ less than 0.05 . The adequacy of the model was also evaluated by developing a normal probability plot of the residuals. The residuals are normally distributed if the points on the plot follow a straight line. As observed in Figure 3, the residual behavior follows a normal distribution, which confirmed the normality assumption. Therefore, the quadratic model built is adequate. The value of determination coefficient $\left(\mathrm{R}^{2}=0.9860\right)$ indicated that $98.60 \%$ of the variability observed in data can be explained by the model for color removal and this also means that only about $1.4 \%$ of the total variable was not explained by the model. The value of the adjusted determination coefficient $\left(\mathrm{R}^{2}{ }_{\text {Adj }}=0.9608\right)$ is high, showing that the model was highly significant.

Table 4. Analysis of variance (ANOVA) for MO removal from Box-Behnken design.

\begin{tabular}{|c|c|c|c|c|c|}
\hline Variation Source & $\begin{array}{c}\text { Degree of } \\
\text { freedom }\end{array}$ & Sum of square & $\begin{array}{c}\text { Adjusted mean } \\
\text { square }\end{array}$ & F-Value & P-Value \\
\hline Model & 9 & 4787.72 & 531.97 & 39.16 & 0.000 \\
\hline Residual Error & 5 & 67.92 & 13.58 & \\
\hline Lack-of-Fit & 3 & 67.66 & 22.55 & \\
\hline Pure Error & 2 & 0.26 & 0.13 & \\
\hline Total & 14 & 4855.65 & & \\
\hline
\end{tabular}

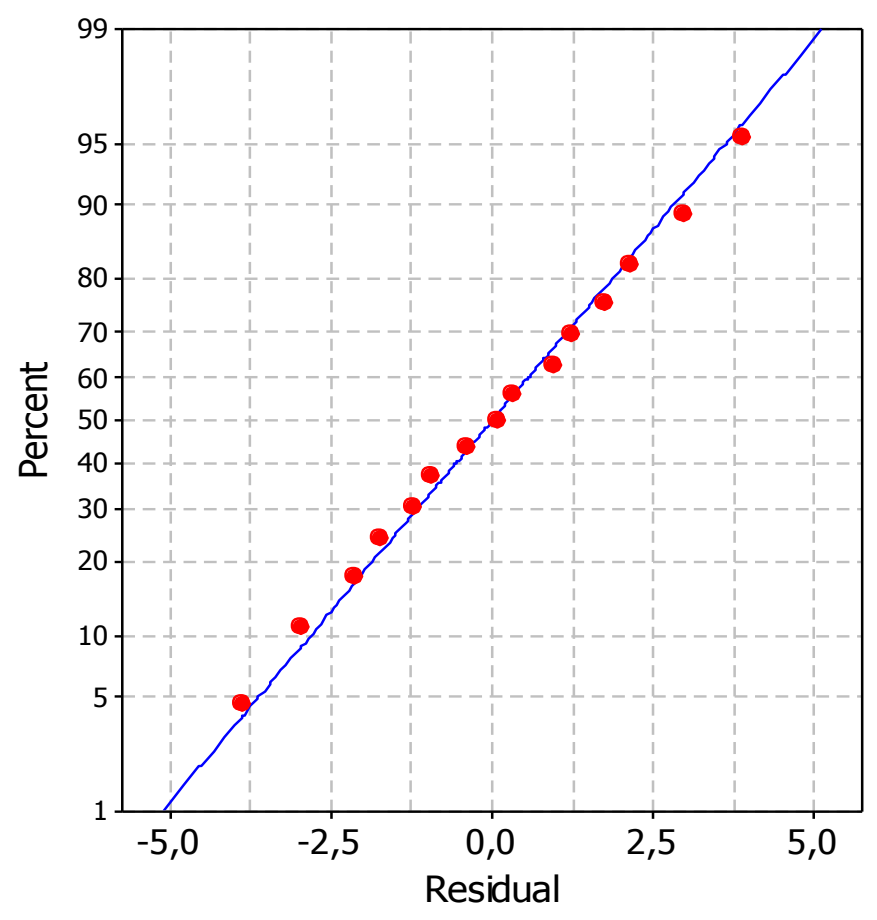

Figure 3. Normal probability plot of residuals for color removal

Pareto analysis was also used to facilitate interpretation of the results and was applied based on the following equation $28,29,30$ :

$$
P_{i}=\frac{b_{i}^{2}}{\sum b_{i}^{2}} \times 100 \quad(i \neq 0)
$$

Where, $b$ represents the related regression coefficient of the parameter. In Figure 4, the Pareto chart illustrates the percentage effect of each factor on the response. It can be seen that current intensity $(7.22 \%)$ and electrolysis time $(24.5 \%)$ were statically significant whereas current density $(46.23 \%)$ had the highest effect on color removal efficiency by EO process. Moreover, the interaction of $\mathrm{pH}$ with electrolysis time $(7.51 \%)$ was also considered significant while the other terms have just a modest effect. 


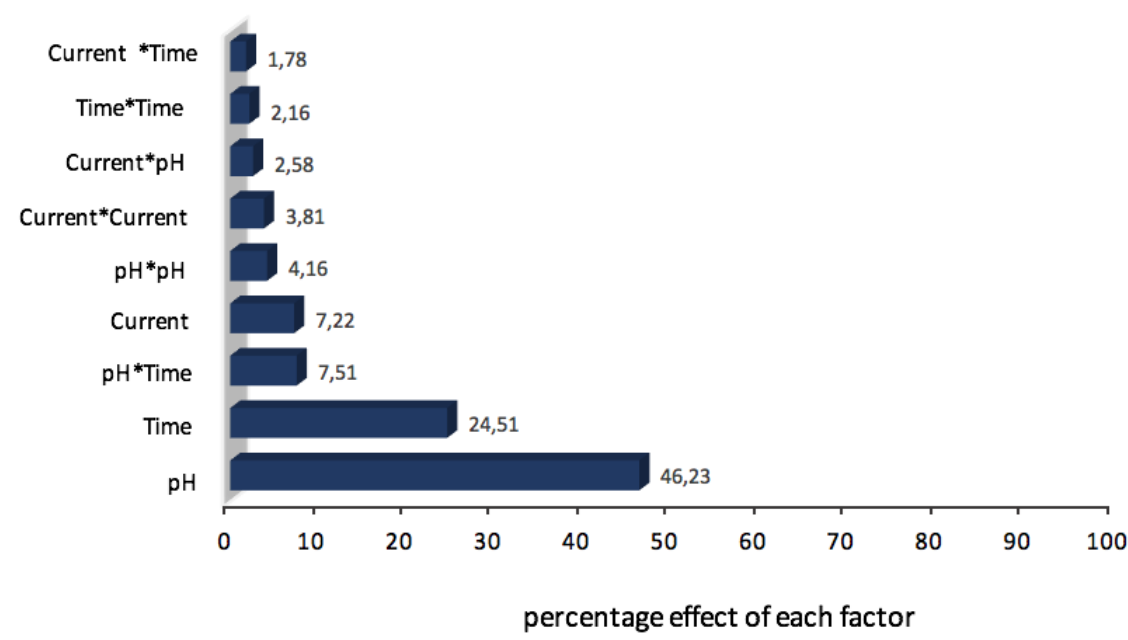

Figure 4. Pareto graphic analysis.

\section{Response surface and contour plots for MO color removal efficiency}

The response surface and contour plots were developed based on the model Eq (6), which were represented as a function of two variables, while the third was kept constant at the center level. By these plots is then possible to understand the influence of independent variables and their interactions on the response. The effect of interaction between initial solution $\mathrm{pH}$ and electrolysis time on color removal efficiency is shown in Figure 5, at a constant current intensity of 4A and a dye concentration of $50 \mathrm{mg} / \mathrm{L}$. The response surface plot shows that the color removal increased considerably when prolonging electrolysis time at the highest $\mathrm{pH}$ of 10 and slightly at the lowest $\mathrm{pH}$ of 4 . A similar trend was also observed for $\mathrm{pH}$, but the response was sharply increased when decreasing $\mathrm{pH}$ at short electrolysis time $(30 \mathrm{~min})$ and slightly increased at long electrolysis time (90 min). It is known that $\mathrm{pH}$ is an important parameter affecting the electrochemical reaction on the electrode surface ${ }^{31}$. The optimum $\mathrm{pH}$ range for dye removal was at acidic $\mathrm{pH}$, which is probably due to the effect of $\mathrm{pH}$ on the concentrations of existing active chlorine species in the solution ${ }^{32}$. It has been reported that low $\mathrm{pH}$ leads to more efficient mediated oxidation of organic pollutants with these species. Chlorine is the predominant specie up to $\mathrm{pH}$ near 3.0, hypochlorous is produced in the $\mathrm{pH}$ range from 3 to 8 , and hypochlorite at $\mathrm{pH}>8.0^{33}$. Therefore, higher rate of degradation at low $\mathrm{pH}$ may be due to higher oxidation potential of chlorine $\left(\mathrm{E}^{0}=1.36 \mathrm{~V}\right.$ vs $\mathrm{SHE})$ and hypochlorous acid $\left(\mathrm{E}^{0}=1.49 \mathrm{~V}\right.$ vs $\left.\mathrm{SHE}\right)$ rather than hypochlorite $\left(\mathrm{E}^{0}=0.89 \mathrm{~V}\right.$ vs $\left.\mathrm{SHE}\right)$.
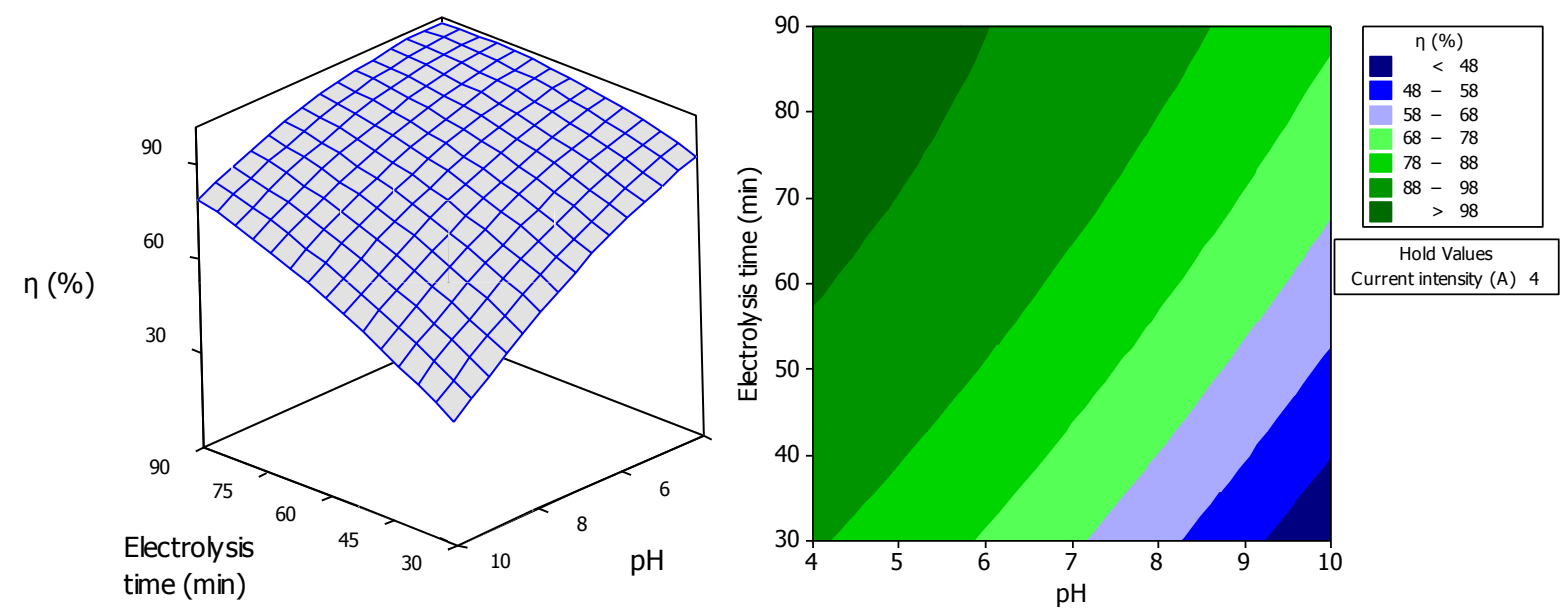

Figure 5. The response surface and contour plots of color removal efficiency as the function of electrolysis time (min) and initial solution $\mathrm{pH}$.

The effect of interaction between current intensity and initial solution $\mathrm{pH}$ on color removal efficiency is presented in the response surface plot of Figure 6 for initial MO concentration of $50 \mathrm{mg} / \mathrm{L}$ and electrolysis time of $60 \mathrm{~min}$. As it is obvious from Figure 6, color removal efficiency increases slightly with increasing current intensity at the highest $\mathrm{pH}$ of 10 , but it increases much more slightly at the lowest $\mathrm{pH}$ of 4 , 
from 3 to $4.25 \mathrm{~A}$, and then decreases from 4.25 to $5 \mathrm{~A}$. Moreover, a strong enhancement of the response can be observed when decreasing $\mathrm{pH}$ at $3 \mathrm{~A}$, which increase slightly at $5 \mathrm{~A}$. The presumed reason is that the increase of current intensity during electrooxidation enhances active chlorine generation that destroys more rapidly the conjugated chromophore system of MO, which eventually led to a greater color removal rate ${ }^{23}$. However, the removal rate did not increase as expected with further increase in the current density. Considering that the mediated oxidation of COD by electrogenerated active chlorine is the main process, this behavior could be related to the less production of hypochlorite, which under higher current densities, convert to a chloro oxidants of higher oxidation states (Eq. (9) ${ }^{34}$. In addition, the concomitant rise in the rate of parasitic anodic oxygen evolution reaction could also contribute and negatively affect the degradation efficiency (Eq. (10)) ${ }^{16}$.

$$
\begin{aligned}
& 6 \mathrm{OCl}^{-}+3 \mathrm{H}_{2} \mathrm{O}+6 \mathrm{e}^{-} \rightarrow 2 \mathrm{ClO}_{3}+4 \mathrm{Cl}^{-}+6 \mathrm{H}^{+}+3 / 2 \mathrm{O}_{2} \\
& 2 \mathrm{H}_{2} \mathrm{O} \rightarrow \mathrm{O}_{2}+4 \mathrm{H}^{+}+4 \mathrm{e}^{-}
\end{aligned}
$$

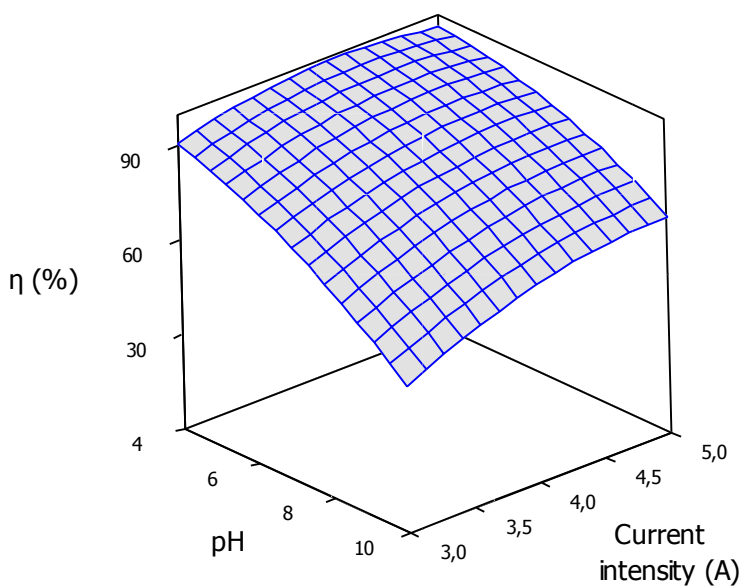

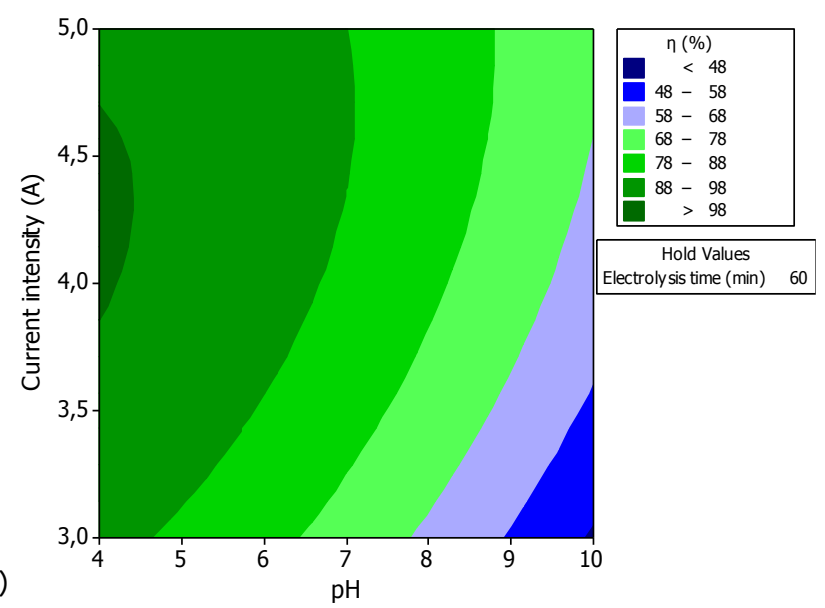

Figure 6. The response surface and contour plots of color removal efficiency as the function of initial solution $\mathrm{pH}$ and current intensity.

Figure 7 illustrates the response surface and contour plot for the effect of interaction between applied current intensity and electrolysis time on color removal efficiency for initial MO concentration of $50 \mathrm{mg} / \mathrm{L}$ and $\mathrm{pH}$ of 7 . As can be seen, an increase of current intensity resulted in an increase of response considerably at the lowest electrolysis time of $30 \mathrm{~min}$ and slightly at the highest electrolysis time of $90 \mathrm{~min}$. On the other hand, the color removal efficiency was

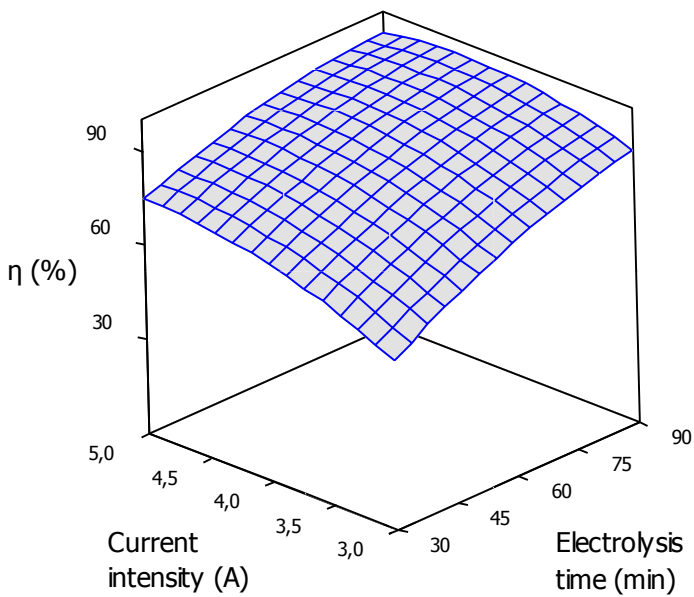

strongly enhanced when increasing current intensity at the lowest electrolysis time of $30 \mathrm{~min}$, but rose slightly at the highest electrolysis time of $90 \mathrm{~min}$ from 3 to $4.6 \mathrm{~A}$ and then slightly decreased from 4.6 to $5 \mathrm{~A}$. The fact that oxidation rate was not affected at increased electrolysis time can be explained by the accumulation of by-products, such as carboxylic acids, that are quite stable against further attack at $\mathrm{Ti} / \mathrm{Pt}$ electrodes ${ }^{35}$.

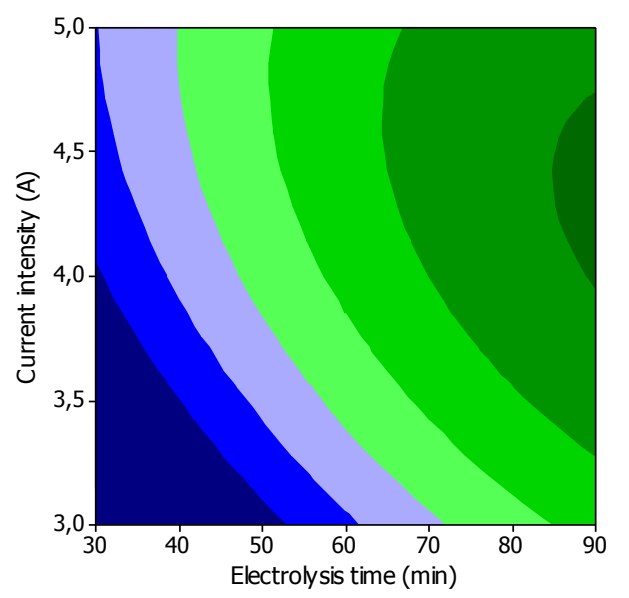

Figure 7. The response surface and contour plots of color removal efficiency as the function of electrolysis time and current intensity. 


\section{Response optimization for MO color removal}

In this study, Numerical optimization was employed to determine the optimum values of the process variables for maximum $\mathrm{MO}$ color removal efficiency, from the model obtained using the experimental data. The optimum conditions for color removal were obtained based on RSM and desirability functions. The optimum values of the process variables for the maximum color removal efficiency were 4 .6A, 4 and 65 min for current intensity, initial solution $\mathrm{pH}$ and electrolysis time, respectively. Under these conditions, $98.92 \%$ color removal was predicted based on desirability function of 1.00. At the optimum process parameters, the observed value of color removal efficiency was found to be $97.51 \%$ which confirms close to the predicted value. These results confirm that the strategy to optimize the color removal conditions by RSM for the treatment of MO with electrooxidation was successful.

\section{Energy consumption}

For industrial-scale applications, energy consumption is an important parameter that can evaluate the economic feasibility of wastewater treatment using electrooxidation process. In this work, the energy consumption per $1 \mathrm{~m}^{3}$ of treated wastewater was calculated as follows:

$\mathrm{Ec}\left(\mathrm{kWh} / m^{3}\right)=\frac{I t U_{c e l l}}{V_{R} * 3600}$

Where $\mathrm{U}_{\text {cell }}$ is the applied voltage $(\mathrm{V}), \mathrm{I}$ is the applied current (A), $t$ is the electrolysis time (s), and $\mathrm{V}_{\mathrm{R}}$ is the reactor volume (L). Ec values at different applied current intensities and initial $\mathrm{pH}$ solution are presented in Table 5. Ec is shown to be affected by the studied parameters. The energy consumption for complete $\mathrm{MO}$ removal increased with an increase in current intensity (from $17.18 \mathrm{kWh} . \mathrm{m}^{-3}$ at $3 \mathrm{~A}$ to 19.69 $\mathrm{kWh} \cdot \mathrm{m}^{-3}$ at $5 \mathrm{~A}$ ), which could be attributed to the rise of cell potential and secondary reactions ${ }^{18,36}$. Moreover, an increase in initial $\mathrm{pH}$ solution leads to higher Ec. This behavior is due to an extended electrolysis time required for total color removal at higher $\mathrm{pH}$ solution, which is disadvantageous for industrial-scale application.

Table 5. Energy consumption, Ec, for MO oxidation.

\begin{tabular}{|l|c|c|c|}
\hline Parameters & Value & Color removal (\%) & E (kWh.m $\left.\mathbf{~}^{-\mathbf{3}}\right)$ \\
\hline Current density (A) & 3 & 96.58 & 17.18 \\
\hline & 4 & 99.14 & 18.66 \\
\hline $\mathbf{p H}$ & 5 & 98.98 & 19.69 \\
\hline & 4 & 98.74 & 11.81 \\
\hline
\end{tabular}

\section{Conclusion}

The present study has proven that the response surface methodology using Box-Behnken design is an effective technique to investigate methyl orange degradation by electrooxidation process. Three factors (current intensity, initial $\mathrm{pH}$ and electrolysis time) were studied. The effects of the selected parameters on the MO color removal efficiency were evaluated. The current intensity was found to be less significant than initial $\mathrm{pH}$ and electrolysis time. The analysis of variance (ANOVA) indicated that the proposed regression model based on Box-Behnken design was significant and could fit the experimental data well. Based on the proposed model, the optimum conditions for a maximum percentage of color removal efficiency were found to be $4.6 \mathrm{~A}, \mathrm{pH} 4$ and $65 \mathrm{~min}$. Under these optimum values and at a dye concentration and temperature of $50 \mathrm{mg} / \mathrm{L}$ and $25^{\circ} \mathrm{C}$, respectively, a color removal rate of $98.51 \%$ can be achieved. The experimental value was in agreement with the predicted value indicating the reliability of the method used.

\section{References}

1- X. Li, X. Li, W. Yang, X. Chen, W. Li, B. Luo, K. Wang, Preparation of 3D $\mathrm{PbO}_{2}$ nanospheres@ $\mathrm{SnO}_{2}$ nanowires/Ti electrode and its application in Methyl Orange degradation, Electrochimica Acta, 2014, 146, 15-22.

2- A. El-Ghenymy, F. Centellas, J. A. Garrido, R. M. Rodreguez, I. Sires, P. L. Cabot, E. Brillas, Decolorization and mineralization of Orange $\mathrm{G}$ azo dye solutions by anodic oxidation with a boron-doped diamond anode in divided and undivided tank reactors, Electrochimica Acta, 2014, 130, 568-576.

3- C. Ramírez, A. Saldaña, B. Hernández, R. Acero, R. Guerra, S. Garcia-Segura, E. Brillas, J. M. Peralta-Hernández, Electrochemical oxidation of methyl orange azo dye at pilot flow plant using BDD technology, J. Ind. Eng. Chem., 2013, 19, 571-579.

4- S. Raghu, C. W. Lee, S. Chellammal, S. Palanichamy, C. A. Basha, Evaluation of electrochemical oxidation techniques for degradation of dye effluents-A comparative 
approach, J. Hazard. Mater., 2009, 171, 748-754.

5- V. M. Vasconcelos, C. Ponce-de-León, J. L. Nava, M. R. V. Lanza, Electrochemical degradation of RB-5 dye by anodic oxidation, electro-Fenton and by combining anodic oxidation-electro-Fenton in a filter-press flow cell, Journal of Electroanalytical Chemistry, 2015, 765, 179-187.

6- E. Sharifpour, E. Alipanahpour Dil, A. Asfaram, M. Ghaedi, A. Goudarzi, Optimizing adsorptive removal of malachite green and methyl orange dyes from simulated wastewater by $\mathrm{Mn}$-doped $\mathrm{CuO}-\mathrm{Nanoparticles} \mathrm{loaded} \mathrm{on}$ activated carbon using CCD-RSM: Mechanism, regeneration, isotherm, kinetic, and thermodynamic studies, Appl. Organomet. Chem., 2019, 33, e4768.

7- N. Rahman, N. C. Dafader, A. R. Miah, S. Shahnaz, Efficient removal of methyl orange from aqueous solution using amidoxime adsorbent, Int. J. Environ. Stud., 2018, 00, $1-14$.

8- T. K. F. S. Freitas, C. A. Almeida, D. D. Manholer, H. C. L. Geraldino, M. T. F de Souza, J. C. Garcia, In Detox Fashion: waste water treatment; ed. by S.S. Muthu; Springer: Singapore, 2018, pp. 27-79.

9- K. El Hassani, D. Kalnina, M. Turks, B. H. Beakou, A. Anouar, Enhanced degradation of an azo dye by catalytic ozonation over $\mathrm{Ni}$ containing layered double hydroxide nanocatalyst, Sep. Sci. Technol., 2019, 210, 764-774.

10- J. J. Murcia, Á. C. Cely, H. A. Rojas, M. C. Hidalgo, J. A. Navío, Fluorinated and Platinized Titania as Effective Materials in the Photocatalytic Treatment of Dyestuffs and Stained Wastewater Coming from Handicrafts Factories. Catalysts., 2019, 9, 179.

11- I. Sir, P. Llu, F. Centellas, A. Garrido, R. Mar, C. Arias, E. Brillas, Electrochemical degradation of clofibric acid in water by anodic oxidation Comparative study with platinum and boron-doped diamond electrodes, Electrochimica Acta, 2006, 52, 75-85.

12- S.B. Dimitrijević, S.P. Dimitrijević, M.D. Vuković, Modern water treatment by electrochemical oxidation - a review, Tmt, 2013, 10-11.

13- K. Rajkumar, M. Muthukumar, Response surface optimization of electro-oxidation process for the treatment of CI Reactive Yellow 186 dye: reaction pathways, Appl. Water Sci., 2017, 7, 637-652.

14- S. Cotillas, J. Llanos, P. Cañizares, D. Clematis, G. Cerisola, M. A. Rodrigo, M. Panizza, Removal of Procion Red MX-5B dye from wastewater by conductive-diamond electrochemical oxidation. Electrochimica Acta, 2018, 263, 1-7.
15- I. Elaissaoui, H. Akrout, S. Grassini, D. Fulginiti, L. Bousselmi, Effect of coating method on the structure and properties of a novel $\mathrm{PbO}_{2}$ anode for electrochemical oxidation of Amaranth dye. Chemosphere, 217, 2019, 26-34.

16- E. Isarain-Chávez, M. D. Baró, E. Rossinyol, U. Morales-Ortiz, J. Sort, E. Brillas, E. Pellicer, Comparative electrochemical oxidation of methyl orange azo dye using $\mathrm{Ti} / \mathrm{Ir}-\mathrm{Pb}, \mathrm{Ti} / \mathrm{Ir}-\mathrm{Sn}$, $\mathrm{Ti} / \mathrm{Ru}-\mathrm{Pb}, \mathrm{Ti} / \mathrm{Pt}-\mathrm{Pd}$ and Ti/RuO2 anodes, Electrochimica Acta, 2017, 244, 199-208.

17- F. Ghanbari, M. Moradi, In Advanced Nanomaterials for Wastewater Remediation; Ed by R.K. Gautam, M.C. Chattopadhyaya; CRC Press LLC: London, 2016.

18- Faja.seppur.2017.01.A. S. Fajardo, R. C. Martins, D. R. Silva, R. M. Quinta-Ferreira, C. A. Martínez-Huitle, Electrochemical abatement of amaranth dye solutions using individual or an assembling of flow cells with Ti/Pt and Ti/Pt-SnSb anodes. Sep. Purif. Technol., 2017, 179, 194-203.

19- M. Amini, H. Younesi, N. Bahramifar, A. Akbar, Z. Lorestani, F. Ghorbani, A. Daneshi, M. Sharifzadeh, Application of response surface methodology for optimization of lead biosorption in an aqueous solution by Aspergillus niger, J. Hazard. Mater., 2008, 154, 694-702.

20- R. O. Cristóvão, C. Gonçalves, C. M. Botelho, R. J. Martins, R. A. Boaventura, Chemical oxidation of fish canning wastewater by Fenton's reagent, J. Environ. Chem. Eng., 2014, 2, 2372-2376.

21- R. H. Myers, D. C. Montgomery, C. M. Anderson-Cook, Response Surface Methodology: Process and Product Optimization using Designed Experiments; ed. by R. H. Myers; John Wiley \& Sons: New Jersey, 2009.

22- M. Danish, W. A. Khanday, R. Hashim, N. S. B. Sulaiman, M. N. Akhtar, M. Nizami, Application of optimized large surface area date stone (Phoenix dactylifera) activated carbon for rhodamin $\mathrm{B}$ removal from aqueous solution: Box-Behnken design approach, Ecotoxicol. Environ. Saf., 2017, 139, 280-290.

23- L. Adlnasab, N. Shekari, A. Maghsodi, Optimization of arsenic removal with $\mathrm{Fe}_{3} \mathrm{O}_{4} @$ $\mathrm{Al}_{2} \mathrm{O}_{3} @ \mathrm{Zn}-\mathrm{Fe} \mathrm{LDH}$ as a new magnetic nano adsorbent using Box-Behnken design, J. Environ. Chem. Eng., 2019, 7, 102974.

24- N. C. Fernandes, L. B. Brito, G. G. Costa, S. F. Taveira, M. S. S. Cunha-Filho, G. A. R. Oliveira, R. N. Marreto, Removal of azo dye using Fenton and Fenton-like processes: Evaluation of process factors by Box-Behnken design and ecotoxicity tests, Chem.Biol. Interact., 2018, 291, 47-54. 
25- A. Alaoui, K. EL Kacemi, K. EL ass, A. Kitane. Application of Box-Behnken design to determine the optimal conditions of reductive leaching of $\mathrm{MnO}_{2}$ from manganese mine tailings, Trans. Indian Inst. Met., 2015, 56, 134-141.

26- H. Zhang, X. Ran, X. Wu, D. Zhang, Evaluation of electro-oxidation of biologically treated landfill leachate using response surface methodology, J. Hazard. Mater., 2011, 188, 261-268.

27- H. Zhang, Y. Li, X. Wu, Statistical Experiment Design Approach for the Treatment of Landfill Leachate by Photoelectro-Fenton Process, Journal of Environmental Engineering, 2012, 138, 278-286.

28- M. Ahmadi, F. Ghanbari, S. Madihi-Bidgoli, Photoperoxi-coagulation using activated carbon fiber cathode as an efficient method for benzotriazole removal from aqueous solutions: modeling, optimization and mechanism, J. Photochem. Photobiol. A. Chem., 2016, 322, 85-94.

29- M.Moradi, F. Ghanbari, M. Manshouri, K. A. Angali, Photocatalytic degradation of azo dye using nano- $\mathrm{ZrO}_{2} / \mathrm{UV} /$ Persulfate: Response surface modeling and optimization. Korean J. Chem. Eng., 2016, 33, 539-546.

30- M. Moradi, F. Ghanbari, E.M. Tabrizi, Removal of Acid Yellow 36 using BoxBehnken designed photoelectro-Fenton : A study on removal mechanisms, Toxicol. Environ. Chem., 2015, 97, 700-709.

31- H. Zhang, X. Ran, X. Wu, D. Zhang, Evaluation of electro-oxidation of biologically treated landfill leachate using response surface methodology, J. Hazard. Mater., 2011, 188, 261-268.

32- F. Zhang, C. Feng, W. Li, J. Cui, Indirect electrochemical oxidation of dye wastewater containing Acid Orange 7 using $\mathrm{Ti} / \mathrm{RuO}_{2}-\mathrm{Pt}$ electrode, Int. J. Electrochem. Sci., 2014, 9, 943-954.

33- C. A. Martinez-Huitle, M. A. Rodrigo, I. Sires, O. Scialdone, Single and Coupled Electrochemical Processes and Reactors for the Abatement of Organic Water Pollutants: A Critical Review, Chem. Rev., 2015, 115, 13362-13407.

34- D. A. Coledam, J. M. Aquino, R. C. RochaFilho, N. Bocchi, S. R. Biaggio, Influence of chloride-mediated oxidation on the electrochemical degradation of the direct black 22 dye using boron-doped diamond and $\beta-\mathrm{PbO}_{2}$ anodes, Química Nova, 2014, 37, 1312-1317.

35- A. D. Hiwarkar, S. Singh, V. C. Srivastava, I. D. Mall, Mineralization of pyrrole, a recalcitrant heterocyclic compound, by electrochemical method: Multi-response optimization and degradation mechanism, J. Environ. Manage., 2017, 198, 144-152.

36- L. Labiadh, A. Barbucci, M. P. Carpanese, A. Gadri, S. Ammar, M. Panizza, Direct and indirect electrochemical oxidation of Indigo Carmine using $\mathrm{PbO}_{2}$ and TiRuSnO 2 , J. Solid. State. Electrochem., 2017, 21, 2167-2175. 